Červenka, J., Jacobson, D. E., and Gorlin, R. J. (1971). Fluorescing structures of human metaphase chromosomes. Detection of 'Y body'. American fournal of Human Genetics, 23, 317-324.

Christensen, K. R., Friedrich, U., Jacobsen, P., Jensen, K., Nielsen, J., and Tsuboi, T. (1970). Ring chromosome 18 in mother and daughter. Fournal of Mental Deficiency Research, 14, 49-67.

De Grouchy, J. (1969). The 18p-, 18q - and 18r syndromes. Birth Defects: Original Article Series, V, 5, pp. 74-87. National Foundation-March of Dimes, New York.

Feingold, M., Schwartz, R. S., Atkins, L., Anderson, R., Bartsocas, C. S., Page, D. L., and Littlefield, J. W. (1968). IgA deficiency associated with partial deletion of chromosome 18. Fournal of Clinical Investigation, 47, 34a.

Feingold, M., Schwartz, R. S., Atkins, L., Anderson, R., Bartsocas, C. S., Page, D. L., and Littlefield, J. W. (1969). IgA deficiency associated with partial deletion of chromosome 18. American fournal of Diseases of Children, 117, 129-136.

Finley, S. C., Cooper, M. D., Finley, W. H., Uchida, I. A., Noto, T. A., and Roddam, R. F. (1969). Immunological profile in a chromosome 18 deletion syndrome with IgA deficiency. fournal of Medical Genetics, 6, 388-393.

Haddad, Z. H., Allen, R. F., Towner, J. W., and Wilson, M. G. (1969). IgA, IgM, and partial deletion of chromosome 18. Lancet, 1, 678 .

Hecht, F. (1969). IgA and partial deletions of chromosome 18. Lancet, 1, 100-101.

Jansch, M. E., May, J. B., and LaMarche, P. H. (1970). $18 \mathrm{p}-/ \mathrm{Gq}$ - mosaicism in a girl with absent IgA. Case represents an unusual mosaicism of two rare genetic anomalies. Rhode Island Medical fournal, 53, 623-625.

Jensen, K., Christensen, K. R., Jacobsen, P., Nielsen, J., Friedrich, U., and Tsuboi, T. (1969). Ring chromosome 18 and gammaM-globulin abnormality. Lancet, 2, 497-498.

Michaels, D. L., Go, S., Humbert, J. R., Dubois, R. S., Stewart, J. M., and Ellis, E. F. (1971). Intestinal nodular lymphoid hyperplasia, hypogammaglobinemia, and hematologic abnormalities in a child with a ring 18 chromosome. Fournal of Pediatrics, 79, 80-88.

Murken, J. D., Salzer, G., and Kunze, D. (1970). Ringchromosom Nr. 18 und fehlendes IgA bei einem 6 jährigen Mädchen $(46, \mathrm{XX}$, 18r). Zeitschrift für Kinderheilkunde, 109, 1-10.

Rohde, R. A., Lee, A., and Sapin, S. (1963). A new trisomytranslocation chromosome (long-arm E/E). Lancet, 2, 13091310.

Rudd, N. L. and Lamarche, P. H. (1971). Gene deletion and duplication effects on phenotype and gamma globulin levels. Fournal of Medical Genetics, 8, 97-106.

Ruvalcaba, R. H. A. and Thuline, H. C. (1969). IgA absence associated with short arm deletion of chromosome No. 18. Fournal of Pediatrics, 74, 964-965.

Stewart, J. M., Go, S., Ellis, E., and Robinson, A. (1970). Absent IgA and deletions of chromosome 18. Fournal of Medical Genetics, 7, 11-19.

Wertelecki, W. and Gerald, P. S. (1971). Clinical and chromosomal studies of the $18 \mathrm{q}$ - syndrome. Fournal of Pediatrics, 78, 44-52.

Yanagisawa, S. (1971). A case of $18 q+$ in a girl with severe mental retardation. Chromosome Information Service (Tokyo), no. 12, 1213.

\section{A Double Aneuploid Mosaic: Trisomy 13 and $\mathrm{XXY}^{*}$}

We have examined a liveborn male who showed physical features of trisomy 13 syndrome and was

Received 22 February 1972

- This study was supported in part by Grant 286 from Maternal and Child Health Service, United States Public Health Service. found to have $47, \mathrm{XY}, 13+/ 48, \mathrm{XXY}, 13+$ mosaicism. To our knowledge, this is the first report of trisomy 13 and an XXY sex chromosome complement coexisting in a liveborn individual.

\section{Case Report}

The patient, a Caucasian male, was born to a 17 -yearold primigravida mother and a 19-year-old father. The father had a son by a prior union. The remainder of the pedigree was unremarkable. Both parents had taken lysergic acid diethylamide (LSD) 2 years before the pregnancy. The infant was the product of an apparently normal 36-week gestation and vertex delivery. Birth weight was $1480 \mathrm{~g}$, length $42 \mathrm{~cm}$, and head circumference $29 \mathrm{~cm}$. The anterior fontanelle was large; the sagittal suture was $1 \mathrm{~cm}$ in each diameter. There was a bony defect $1.6 \times 2 \mathrm{~cm}$ in the parieto-occipital region through which the meninges were seen (Fig. 1). The parietal bones overlapped the frontal and occipital bones. The face had an inverted triangular shape with a broad forehead and hypoplastic left eye (Fig. 2). The right eye was normal. The nose was large and prominent, the mouth was small and the ears were low set. The neck showed redundant skin folds. There was a ventral hernia 1.5 $\mathrm{cm}$ above the umbilicus. Except for an undescended left testis, the genitalia were normal for a male infant. Both hands had a simian crease and an extra ulnar digit. The feet were rocker bottom in shape and showed a wide space between the 1st and 2nd toes. The remainder of the physical examination was normal. The infant was alert, cried vigorously, and showed no abnormal neurological findings. Shortly after admission he became cyanotic and was given antibiotics for suspected

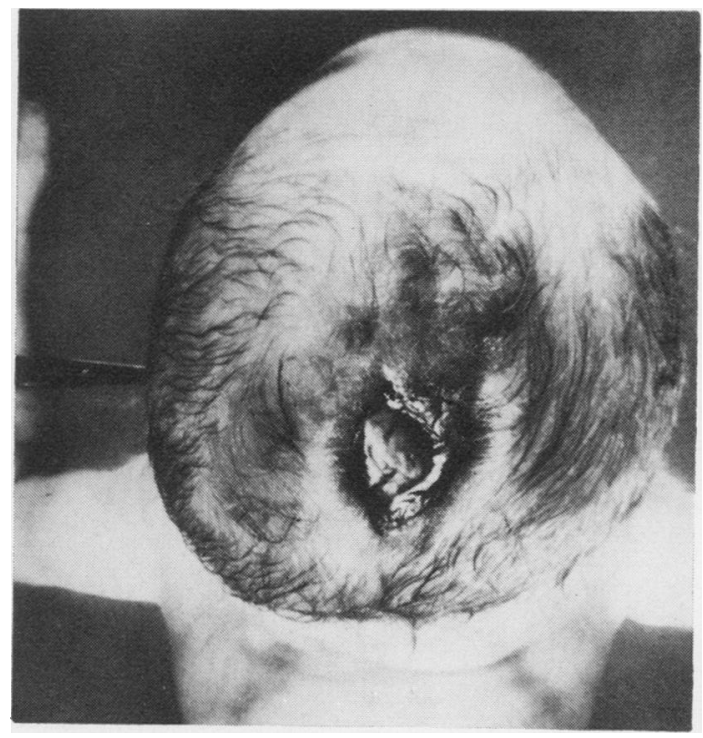

Fig. 1. Scalp view of the propositus. 


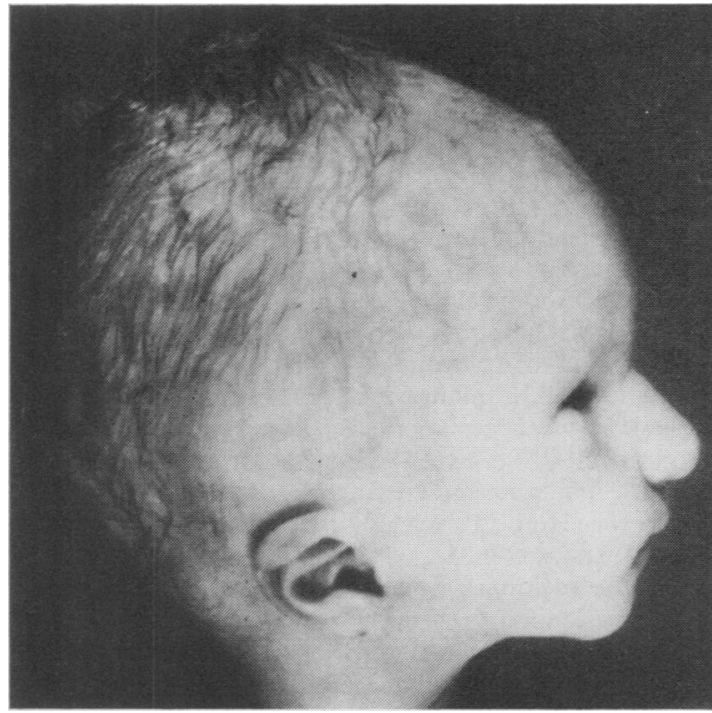

Fig: 2. Side view of the propositus.

septicaemia. He developed tonic seizures and died at 10 hours of age.

In addition to the clinical findings, necropsy examination revealed a hypoplastic left optic nerve about half the size of the right optic nerve. The heart, which was normal in size, had a $2 \mathrm{~mm}$ defect between the left atrium and sinus venosus and a high ventricular septal defect. There was an extra left common carotid artery. Also present were hypoplastic thymus, malrotation of the intestines, a Meckel's diverticulum, and accessory spleens. There were only 10 ribs on each side. Microscopic examination revealed aspiration pneumonitis, focal pancreatitis, and thickening of the renal tubular membrane. The thymus showed lymphoid depletion, and the bone marrow revealed a marked granulocytic proliferation.

\section{Chromosome Analysis}

Chromosome analysis (Fig. 3) was done from the patient's blood, skin, and fascia. All of the cells examined from the peripheral blood showed trisomy $\mathrm{D}(47, \mathrm{XY}, \mathrm{D}+)$. Chromosome analysis of skin and fascia showed another cell line with an extra chromosome in the C group; 48,XY,C+, D + (Table I).

TABLE I

CHROMOSOME ANALYSIS

\begin{tabular}{l|c|c|c}
\hline \multicolumn{1}{c|}{ Tissue } & $\begin{array}{l}47, \mathrm{XY}, 13+ \\
\text { (no. of cells) }\end{array}$ & $\begin{array}{c}48, \mathrm{XXY}, 13+ \\
\text { (no. of cells) }\end{array}$ & $\begin{array}{c}\text { Total } \\
\text { Cells Analysed }\end{array}$ \\
\hline Blood & 18 & 0 & 18 \\
Skin & 63 & $8(11 \%)$ & 71 \\
Fascia & 34 & $3(8 \%)$ & 37 \\
\hline
\end{tabular}

One thousand cells from each of the tissue cultures were examined for sex chromatin. Fourteen cellso in the skin culture $(1.4 \%)$ and 47 cells in the fascia culture $(4.7 \%)$ were sex chromatin positive. Sex chromatin nuclei were also observed in sectioned

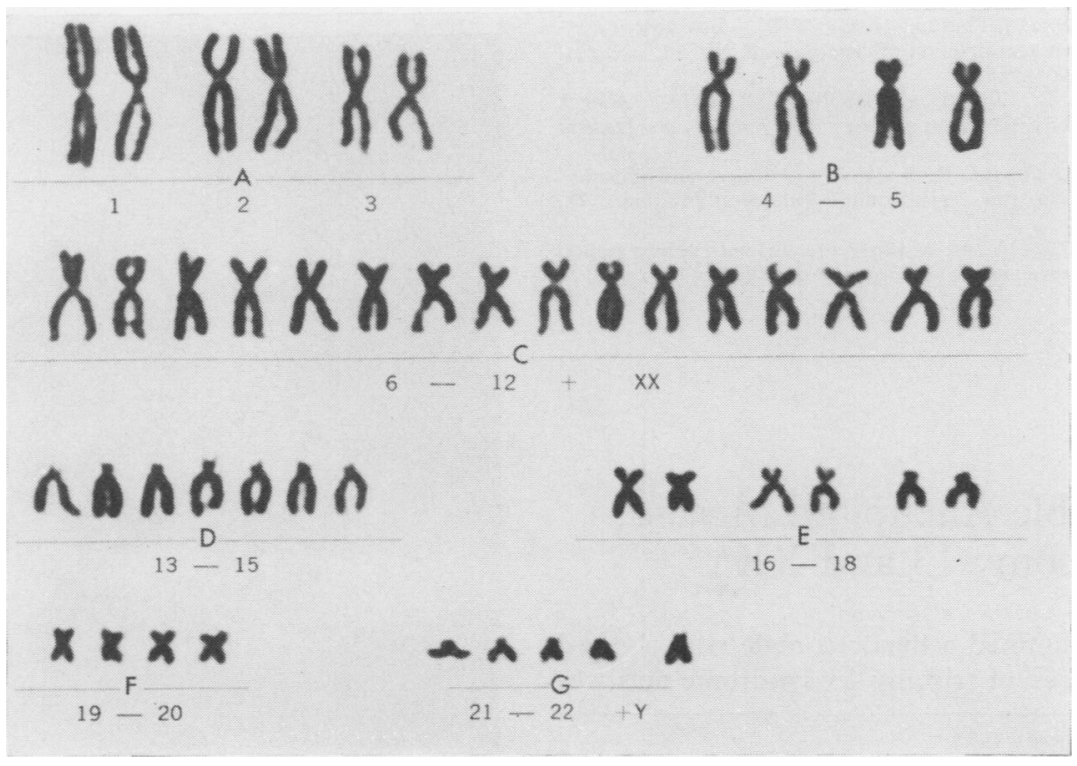

FIG. 3. Karyotype from a fibroblast cell (skin) showing 48,XXY,13 + . 
adrenals. Autoradiography of skin fibroblast culture demonstrated that the cell line with 48 chromosome included a distinctly late-labelled $\mathrm{X}$ chromosome and an extra D chromosome labelling as expected for No. 13. The labelling in the 47 chromosome cell line also confirmed the extra $\mathrm{D}$ to be No. 13. No euploid cells were found. Chromosome analysis of peripheral blood from each parent was normal.

\section{Discussion}

Pergament and Kadotani (1965) found trisomy D and XXY in a tissue culture from the limb-bud of an early spontaneous abortion. Although our patient is the first reported liveborn infant with trisomy 13 and an XXY sex chromosome complement, we are aware of another such infant through a personal communication (C. B. Francisco and C. Herzon). That infant lived 2 hours and also had physical features consistent with trisomy $\mathrm{D}_{1}$ syndrome. It is noteworthy that the double aneuploidy in our patient would have been undetected if only peripheral blood had been examined.

There are at least 4 possibilities for the mechanism by which an individual can be mosaic for single and double aneuploidy. The first is fertilization between a normal gamete and a gamete with an extra chromosome resulting in a trisomic zygote; ie, $47, \mathrm{XY}, 13+$, followed by a subsequent non-disjunction producing a double aneuploid line (48, $\mathrm{XXY}, 13+)$. The other cell line of $46, \mathrm{Y}, 13+$ is presumably non-viable. A second possibility entails an initially euploid zygote followed by 2 nondisjunctional events resulting in $46, \mathrm{XY} / 47, \mathrm{XY}, 13+$ / $48, \mathrm{XXY}, 13+$ cell lines. This explanation is less satisfactory since a normal euploid cell line was not found in our patient. A third possibility is the fertilization of 2 gametes each with an extra chromosome, resulting in a doubly aneuploid zygote; namely, 48,XXY,13+. A later non-disjunction could then result in one cell line trisomic for only the No. 13 chromosome and another cell line of $49, \mathrm{XXXY}, 13$ + , presumably non-viable. A fourth possibility is that of anaphase lag occurring in a double aneuploid 48,XXY,13+ zygote, producing $48, \mathrm{XXY}, 13+/ 47, \mathrm{XY}, 13+$ mosaicism. However, the fact that $48, \mathrm{XXY}, 13+$ is the minor cell line is against it. The simplest explanation involving the fewest number of division errors is the first possibility.

The authors wish to express their gratitude to $\mathrm{Mr}$ David Larkin for the photography and to Mrs Fay Kaplan, Mr Paul Nazarian, Mr Paul Brager, and Mrs Talma Dawson for technical assistance.
REFERENCE

Pergament, E. and Kadotani, T. (1965). A new double aneuploid: XXY D trisomy. Lancet, 2, 695.

Allan J. Ebbin, Rosie Chu Lim, JOSEPH W. TOWNER, and Miriam G. WILSON

Department of Pediatrics, Los Angeles CountyUniversity of Southern California Medical Center and University of Southern California School of Medicine, Los Angeles, California, USA

\section{A Case of Partial 14 Trisomy $47, \mathrm{XY},(14 \mathrm{q}-)+$ and Translocation $\mathrm{t}(9 \mathrm{p}+; 14 \mathrm{q}-)$ in Mother and Brother*}

D group trisomy (13-15) was first described by Patau et al in 1960 . Since then at least 126 cases with cytological confirmation have been reported (Taylor et al, 1970). The phenotypic features have been tabulated and considerable variations noted. In some of these cases the extra chromosome was identified by autoradiographic techniques (Giannelli, 1965) and recently in 2 cases by quinacrine fluorescence (D. A. Miller et $a l, 1971$ ) as a No. 13. The rest have been presumed to be 13 trisomy because of the clinical similarity of the phenotype. A syndrome associated with trisomy of chromosome 14 has not been described. We report here a case trisomic for a large part of chromosome 14 identified by quinacrine fluorescence.

Family studies revealed a translocation, $t(9 p+$; $14 \mathrm{q}-$ ), involving the long arm of chromosome 14 and the short arm of chromosome 9 in the mother and an older sib of the propositus, both phenotypically normal. The case represents transmission, presumably by non-disjunction, of the structurally abnormal chromosome $14(14 \mathrm{q}-)$ from the translocation carrier mother producing a child partially trisomic for $14[47, \mathrm{XY},(14 \mathrm{q}-)+]$.

\section{Family History}

The pedigree is detailed in Fig. 1. The propositus (III.3) was the product of the 3rd pregnancy of a

Received 10 February 1972.

* This study was supported in part by grants from the National Institutes of Health: USPHS 00198-05 (E.M.S.), NS 06882 (G.B.S.), and HD 00339 (W.R.B.). 